\title{
Appointment Robbery: Do Crime Prevention Through Environmental Design Strategies Work? Voices from the Street
}

\author{
Arthur G. Vasquez ${ }^{1}$, Alejandro Rodriguez, Jiwon Suh, \& Maria Martinez-Cosio \\ University of Texas at Arlington
}

\begin{abstract}
Crime Prevention Through Environmental Design (CPTED) theory posits that crime can be reduced with modifications and planning to the physical environment by making involvement in criminal activity more difficult to complete by increasing the visibility of the offender thereby raising the risk of being caught. A new type of criminal opportunity has evolved in the $21^{\text {st }}$ Century with the introduction and explosion of direct e-commerce opportunities with online and app advertisements to buy and sell items through such venues as Craigslist, OfferUp, Letgo, and Facebook Marketplace. This new crime is defined as an 'appointment robbery'. Using interviews of 12 active robbers from a metropolitan area in Texas, this study explored whether or not offenders were deterred from participating in criminal behavior due to the implementation of CPTED strategies. Results from this study suggest that offenders reported that territoriality, natural surveillance, activity support, and access control did serve as deterrents during the decision to commit a robbery. The study examined the original CPTED theory as posited by Jeffery in 1971. The study found support for the original four CPTED strategies.
\end{abstract}

KEYWORDS: Appointment Robbery, Crime Prevention, Crime Prevention Through, Environmental Design, Qualitative, Robbery.

\section{Introduction}

A new type of criminal opportunity has evolved in the $21^{\text {st }}$ Century with the introduction and explosion of direct e-commerce opportunities with online and app advertisements to buy and sell items through such venues as Craigslist, OfferUp, Letgo, and Facebook Marketplace. Internetbased e-commerce websites, such as Craigslist, OfferUp, Letgo, and Facebook Marketplace have been described as the largest online classified advertisements where one can find anything needed from a new car to a used toy. These Internet and app-based e-commerce websites provide offenders a wide variety of appealing targets for various types of predatory offending (Durkin, 2013). This really is a new marketplace of doing business through apps, which numerous individuals see as an easy and fast way to make extra cash by posting an item they want to sell and then waiting for the highest offer. There are numerous apps and Internet forums that specialize in aiding you to sell personal belongings for fast cash. However, the Consumer Federation of America (2018) reported that when individuals attempt to sell or buy their items by using apps or online advertisements, they increasingly have to deal with potentially being robbed. These new marketplace apps promise

${ }^{1}$ Corresponding author: arthur.vasquez@mavs.uta.edu 
to eliminate the middleman by providing sellers and buyers the opportunity to arrange their own terms and potentially increase their profits. However, unlike older platforms like EBay and Amazon, by which you usually mail the item to a buyer, these newer apps prioritize local buyers to avoid shipping and platform fees, thereby requiring the individual to frequently make the financial exchange in person. This in-person financial exchange increases the risk of being robbed. Across the nation, various jurisdictions report incidents where unsuspecting consumers were placed in dangerous situations after arranging and agreeing to meet face-to-face to buy or sell items such as watches, iPads, and cell phones.

The perception of meeting someone face-to-face to complete a merchandise transaction does seem dangerous; McKenzie's (2011) study argues that over time if there are enough face-toface meetings to exchange money for goods, you will find a certain number of crimes. The study helped to provide a more accurate picture of advertisements and related crime in North America. It stated that in 2010 there were 573 million advertisements, and of these, only 0.00005 percent of those advertisements were connected with a serious crime; which means that that odds of selecting a random advertisement from online and apps that could possible result in a crime is 1 in 2 million, as compared to an individual's odds of 1 in 844,000 of being killed in an airplane crash (2011). As stated, it is safe to say that at least 99 percent of all 'meet-ups' from online and app advertisements are safe, and everyone gets what they sought out to do; make extra money and buy an item at a reduced price. What about that 0.00005 percent? While the odds of an individual picking an advertisement that is associated with a crime is low, when a crime does occur it still results in creating public panic. These public panics are then associated with a fear of crime from using any online or apps to buy/sell merchandise. When the newspapers and broadcast media promote these public panics, they frequently coin a clever name for the specific issue, incident, or crime. For example, previously the notion of 'robbery by appointment' was coined and then materialized as people posted advertisements, left information about the sale of goods on Craigslist, and subsequently found their residences robbed (Lee, 2012).

A point of this paper is to also clearly identify and separate this type of robbery from previously labeled types of robbery. Currently, states, cities, and jurisdictions have not adopted a universal term that clearly describes this new type of offense. Since the type of robbery discussed in this paper is directly connected with setting up an appointment to rob the individual by using an electronical device and/or a cell phone app, it was decided to develop a new label for this type of robbery. The FBI's Uniform Crime Reporting (UCR) program defines robbery "as the taking or attempting to take anything of value from the care, custody, or control of a person or persons by force or threat of force or violence and/or putting the victim in fear" (U.S. Department of Justice, 2010). For the purpose of this paper it has been determined that this new type of criminal offense warrants a new label. Since the offender uses an electronical device and/or a cell phone app to set up the location, target, and financial reward of the robbery, the author has coined this type of offense as an 'appointment robbery'. The definition to be used in this paper for an 'appointment robbery' is based on the FBI's definition, but adds the component of using an electronical device to set up the robbery. Appointment robbery is defined as the taking or attempting to take anything of value from the care, custody, or control of a person or persons by force or threat of force or violence and/or putting the victim in fear by way of using an electronical device and/or a cell phone app to set up the robbery.

$21^{\text {st }}$ Century innovations in technology have generated new opportunities for offenders to commit deviant activities. While new technology has helped several disciplines, the internet and mobile selling apps have also created new forms of unprecedented opportunities for individuals to participate in various types of crimes that would not have been previously available (Durkin, 2013). 
Criminals now have a new way to clearly identify a victim and calculate their reward when deciding to commit a robbery. The main difference between robbing a random victim and selecting a targeted victim from a mobile selling app or an electronic advertisement is that the criminal can determine the precise value of the reward and set the appointment in order to rob the individual. In most cases, individuals (sellers) invite strangers to their place of residence or set up a designated meeting place to purchase items that are listed for sale on such outlets as Craigslist, OfferUp, Letgo and Facebook Marketplace. As a result, these electronic advertisements have provided criminals a new way to commit crimes by directly providing a venue for the criminal to specifically identify their victim, the financial reward, as well as the target location. Various cities have, therefore, decided to respond to this new form of criminal activity by implementing 'safe spaces' to offer a protected area where online buyers and sellers can meet to exchange merchandise. This new response to a $21^{\text {st }}$-Century crime has its foundation in Crime Prevention Through Environmental Design (CPTED). Preventing crime is a complex matter and CPTED has shown it can reduce the possibility of crime with planning and modification to the physical environment by making criminal involvement more difficult to complete or by making the offender more visible and thereby increasing the risk of being caught (Sakip \& Abdullah, 2010).

The purpose of this paper is to assist planners, designers, and policymakers in identifying any potential existing CPTED strategies that work in reducing criminal activity and how to incorporate them either in early planning or in existing policies by using the voices from active robbers. Although a significant body of research can demonstrate the importance of CPTED strategies in crime prevention, there is insufficient research evaluating the performance of CPTED strategies from the perspective of active robbers who have not been identified by law enforcement. Appointment robbery is on the rise across the nation and while most agencies incorporate CPTED strategies to reduce this type of crime, little is known if the actual offender recognizes the CPTED strategies and is deterred. The focus of the following analysis will examine the relationship between active robbers and the original four CPTED strategies introduced by Jeffery (1971). This paper will briefly discuss background information on using technology and crime and then will discuss CPTED to present key findings for the application of the original CPTED strategies. Next, the paper will use the voices of active offenders to investigate if CPTED strategies had an impact on committing a crime or not. The results of the analysis will be presented by using the respondents' own words as it relates to the application of each CPTED strategy. Lastly, the paper will discuss any limitations and potential policy implications derived from the analysis.

\section{Literature Review}

New technology has created new opportunities for various types of criminal activities such as criminal markets in pornography, gambling, pirated music, and illegal drugs (Durkin, 2013). It should be made clear that the Internet does not directly cause crime; however, it is simply a strong communication tool that could potentially intensify and hasten crime (Williams, 2008). On the Internet, there is also a large black market in selling and buying illegally obtained financial and credit card information (Choo \& Smith, 2008). Additionally, classified ads solicited on various types of online and social media apps are forming a new market-place for illegal sexual services and stolen goods (Adler \& Adler, 2006).

New technology allows individuals an opportunity to communicate anonymously (Durkin, 2013). It is this perception of anonymity that can embolden criminogenic behavior and could possibly be a contributing factor in various types of deviant behaviors e.g., cyberstalking, cyberbullying, and cyber harassment (Durkin and Patterson, 2011). The perceived anonymity 
provides the offender the opportunity to operate out in the open and avoid apprehension (Cilluffo, Cardash, \& Whitehead, 2007). The opportunity to participate in criminal behavior increases with the use of anonymous emails, proxy servers, and blocked personal content, which allows the offender to visibly participate in crime and scams with relative freedom (Durkin \& Brinkman, 2009).

Typical computer crimes of the past will continue to evolve as individuals become more technologically savvy as well as gain easier computer access (Davis, 2012). Computer technology decreases the probability of punishment for their indirect involvement and anonymous nature (Williams, 2008). Therefore, it should not be surprising that traditional crimes such as robbery are now being facilitated through an electronic setting. The internet reduces the need for an open-air illegal drug market as well as allows for organized prostitution to solicit electronically (New Jersey Commission on Investigation, 2000). Gangs have been documented to actively recruit new members using the internet and social media (New Jersey Commission on Investigation, 2000; Ortiz, 2018). The Nigerian 419 fraud is a successful type of fraud that shows how easy it is for motivated criminals to find a large number of potential victims since it is estimated that the Nigerian 419 fraud takes $\$ 3$ billion a year from victims (Durkin, 2013).

More recently, the new technology based electronic advertisement websites such as Craigslist, OfferUp, Letgo, and Facebook Marketplace have served as a new format to provide predatory targets for offenders. Craigslist and other online advertisement apps are frequently associated in the news and social media with various types of crimes (Bercovici, 2011). The broadcast media and newspapers frequently apply the label 'Craigslist Rapist' or 'Craigslist Killer' for an array of unfortunate incidents resulting in negative public perception in using any online advertisements (Oravec, 2014). In 2009, Phillip Markoff, known as the 'Craigslist Killer,' targeted women who solicited erotic services on Craigslist (Goodnough \& O'Conner, 2010). In another incident, when a family advertised the sale of a television online, a group of offenders killed the father during a home invasion robbery for the item being sold (Holtz, 2010).

As you have read above, crimes that arise from electronic advertisements and/or apps to complete face-to-face transactions are safer that you would expect. The issue is not that meeting someone from an app to sell/buy something is dangerous; the issue is that there are different responses to the new type of crime, appointment robbery. Cities have responded with implementing 'safe zones' as well as distributing tips on conducting face-to-face financial transactions through various media outlets. Computer based crimes, as compared to traditional type of crimes, frequently do not prompt the same public and political reaction. This results in only a small amount of resources and effort being allocated to typical computer crimes (Hinduja, 2007). Public panic can be created by the media in response to a single 'Craigslist' transaction that went bad, as compared to a typical computer-based crime. Only when technology is used to facilitate a crime that results in an individual directly committing a crime against another (i.e. robbery), is when a computerbased crime will elicit a public response.

\section{Theoretical Background}

Criminologist and others frequently seek to understand why offenders commit a crime based on what Mills (1940) identified as vocabularies of motive, however, this study seeks to understand if strategies of CPTED have an effect on the decision-making skills of offenders to commit a crime. Crime prevention through environmental design emphasizes strategies that could decrease crime by directly concentrating on areas that are frequently targets of crime (Taylor \& Hale, 1986). 
Online shopping with face-to-face monetary exchanges has resulted in providing an offender with a new opportunity to commit a crime. This new opportunity provides the offender with more control over the selection of the reward, target and location. While new technology provided a way for new ecommerce, it also meant that a new response was needed to aid in reducing appointment robbery. One of the innovative responses to reduce crime during the 1960s and 1970s was with Crime Prevention Through Environmental Design (CPTED). CPTED's approach to decreasing crime demonstrated the need for a multi-agency model to increase their accountability for their actions. The new CPTED innovative approach utilized multiple disciplines, including urban design, architecture, criminology, and psychology (Armitage, 2018).

The effect of location on 'crime risk' has been well recognized in the literature. Prior research has found that specific design features play a role in the perceived susceptibility for crime at the individual, street, and neighborhood level (Armitage, 2018). At the property level (microlevel) this includes the absence or presence of explicit design features that can either decrease or increase the property levels' appeal to offenders (Armitage, 2018; 2006; Armitage et al., 2010; Brown \& Altman, 1983; Cromwell et al., 1991; Poyner, 1983; Tseloni et al., 2014). At the neighborhood level (macro-level) this includes distance of the property to the offender's residence (Bennett \& Wright, 1984; Bernasco \& Nieuwbeerta, 2005; Wright \& Decker, 1994), the distance of the property to an interchange of transport (Groff \& LaVigne, 2001), and the distance of the property to a pedestrian walkway (Armitage, 2006; 2013).

Crime prevention through environmental design was initially presented by Jeffery in 1971, who was motivated by the work of Jane Jacobs (1961). Jacobs stressed that diverse land use along with increased pedestrian activity are significant attributes for neighborhood safety. Starting in the 1960s and 1970s, researchers proved how the built design could play a role in preventing crime in place-based approach (Jacobs, 1961; Jeffery, 1971; Newman, 1973). Over the next few decades, the strategies of CPTED started to be accepted as an effective approach in crime reduction (Armitage 2013; Poyner \& Webb 1991). The goal of CPTED is to decrease crime occurrences by manipulating the build, design, management of the built environment, and the natural environment. CPTED focuses on relationships amongst the environment and people while using behavioral and environmental psychology (Cozens \& Love, 2015). More recently, Armitage (2013) defined the aim of CPTED as "The design, manipulation and management of the built environment to reduce crime and the fear of crime and to enhance sustainability through the process and application of measures at the micro(individual building/structure), meso (neighborhood), and macro (national) level" (p. 287). Under CPTED, there are built elements that could sway how individuals respond to environmental clues based upon their perception of the environment (Cozens \& Love, 2015). CPTED's strategies provide for elements that are aimed at discouraging individuals who have a propensity to commit criminal activity, in this case, robbery. Traditional crime prevention typically relies on reactive law enforcement procedures as well as intensive capital investment on mechanical and/or electronic devices; however, CPTED attempts to reduce crime by utilizing natural and mechanical strategies with location design and individual activities which can be implemented proactively at the initial design stage (2015).

This paper will examine the data through the lens of the original CPTED theory proposed by Jeffery (1971) who used the research of Jacobs (1961) to develop a new approach for crime control which was named Crime Prevention Through Environmental Design (CPTED) (Greenberg $\&$ Rohe, 2007). The original CPTED approach is based on the effective use and proper design of the built environment to decrease fear and the occurrences of crime (Crowe, 2000). Prior research identified four strategies that makeup CPTED to modify the built environment for the purpose of decreasing crime (Cozens, 2002; Carter, Carter, \& Dannenberg, 2003; Kajalo \& Lindblom, 2015). 
These four strategies are (1) territoriality, (2) natural surveillance, (3) activity support, and (4) access control.

\section{Territoriality}

Territoriality is the capacity of the physical environment to create perceived zones of territorial influence (Cullen, Agnew, \& Wilcox, 2013). The strategy of territoriality conveys the physical sense of being owned or private with a designed purpose. Territoriality is a design concept that tries to promote a 'sense of ownership' of the space to reduce potential criminal opportunities by motivated offenders. When spaces are clearly defined, it is easier to identify potential offenders. The research found that when territoriality strategies are implemented, it resulted in offenders reevaluating a target's vulnerability, thereby decreasing burglary (Brown \& Altman, 1983). This concept can include symbolic barriers such as small changes in road textures and signage, as well as real barriers such as gates that can clearly define and indicate areas as being public, semi-private, or private (Cozens \& Love, 2015). Some examples of the physical features that help convey this include: walls, fencing, sidewalks, signage, and landscape borders. High rise buildings have weak territoriality because of shared doorways, courtyards, and lobbies (Cullen, Agnew, \& Wilcox, 2013). Consequently, low and mid-rise buildings have higher territoriality since they have private doors, fewer residents, and unique yard space (Cullen, Agnew, \& Wilcox, 2013). Additional research findings also found support in the use of territoriality strategies (Anderson, MacDonald, Bluthenthal, \& Ashwood, 2013; Wortley \& McFarlane, 2011).

\section{Natural Surveillance}

Natural surveillance is the way an area is planned to maximize the possibility of formal or informal observers of the space in order to witness potential suspicious behavior. Surveillance refers to the degree to which potential offenders perceive the likelihood of being seen, even when their perception could be wrong. Surveillance is also obtained by strategic placement of buildings in a development such as making sure that the entrances to the buildings face towards the street. This is done to make sure that sightlines are not blocked by obstructions such as high fences and shrubbery, and to make sure that rooms that face the street are active rooms (i.e., living rooms, kitchen) (Armitage, 2018). Surveillance is the capacity of physical design to provide surveillance opportunities for residents and their agents; this includes such things as the height of the buildings, the number of access routes, placement of buildings, and height and placement of shrubbery/trees (Cullen, Agnew, \& Wilcox, 2013). Under natural surveillance, windows allow residents to survey exterior and interior spaces. Therefore, high rise buildings have weak natural surveillance since there is little or no view of the common and street areas (Cullen, Agnew, \& Wilcox, 2013). Consequently, areas with high degrees of natural surveillance have a reduced level of crime risk (Armitage, 2006; Van der Voordt \& Van Wegen, 1990; Winchester \& Jackson, 1982). Areas that offenders perceive to have a high level of natural surveillance have less likelihood to be vulnerable to crime (Brown \& Bentley, 1993; Nee \& Meenaghan, 2006).

\section{Activity Support}

Activity support pertains to the use of signage and design to promote intended patterns of usage of the public space. The strategy of activity support aims to put activities that are inherently 'unsafe' (i.e., those that involve financial transactions) into areas that are 'safe,' which are areas 
that have a high activity level and that have opportunities for surveillance (Crowe, 2000). The premise is for 'safe' activities to function as magnets to attract ordinary individuals into the specified area, thereby serving to discourage potential offenders from coming into the area (Cozens, Saville, Hillier, 2005). Also, increased levels of activities in mixed use communities have been found to reduce opportunities for crime (Petterson, 1997). While this increases the 'eyes on the street' (Jacobs, 1961), it could also increase the opportunities for crime by providing more potential targets for a motivated offender.

\section{Access Control}

Access control focuses on decreasing opportunities for crime by hindering access to possible targets while also generating a heightened perception level of risk in potential offenders. Access control examines the physical guidance of individuals coming in or going out from an area through strategic placement of exits and entrances, landscaping, fencing, and lighting. The goal of access control is to provide space for an intended user, thereby keeping out individuals that do not belong to the area. This strategy can contain informal (i.e., natural), formal (i.e., law enforcement), and mechanical (i.e., locks) (Cozens, Saville, Hillier, 2005). It has been argued that access control strategies can prevent crime by decreasing the opportunities to offend as well as the rewards of offending (Cornish \& Clarke, 2003). Prior research found that the layout of streets and walkways encouraged activity by pedestrians and thereby reduced crime (Hiller, 2004). There is a correlation between the level of crime and the design features when there are no features to restrict pedestrian movement throughout neighborhoods (Newman, 1972; 1973, 1980; Poyner, 1983, Poyner \& Webb, 1991). Other research found decreased levels of crime when there is some pedestrian movement with busier streets (Hillier \& Shu, 2000). Lastly, there is reduced crime in areas with increased levels of restricted access as compared to areas that have lower levels of restricted access resulting in more crime (Beavon, Brantingham, \& Brantingham, Eck, 1997; 1994; White, 1990).

\section{Methodology}

Qualitative methods were used for this research since it allowed the offenders to openly discuss their personal behaviors and experiences so that the researcher could develop a better understanding of their involvement in appointment robbery as individuals and in the setting of their environment (Berk \& Adams, 1970; Decker \& van Winkle, 1996; Hochstetler, 2001). The study used field research since it consisted of using two types of methods to obtain the data, asking questions and direct observation (Maxfield \& Babbie, 1995; Patton, 2002). Semi-structured interviews were chosen to examine and question their rationale when selecting a target and whether or not they were deterred by environmental or physical features (Patton, 1987). An advantage in using qualitative research for this particular study allowed the researcher to get close enough to gain first-hand experience in the offender's feelings, motives, intentions, and often contradictory and detailed perspective of the social world, all of which are problematic to capture with quantitative methods (Cromwell \& Birzer, 2014; Glassner \& Carpenter, 1985; Polsky, 1967). The sample was purposive and consisted of 12 active appointment robbers from a metropolitan area in Texas. Prior research has defined 'active' offenders as had committed two or more acts of crime within the previous two months and were not presently incarcerated (DeShay, Vasquez, Vieraitis, 2020; Vasquez \& Vieraitis, 2016; Wright, Decker, Redfern, Smith, 1992). All respondents meet this criterion. 
The data were collected through semi-structured interviews in an informal manner, which allowed for the order and content of the questions to vary for each respondent (Patton, 1987; Wright, Decker, Redfern, \& Smith, 1992). The interviewing style permitted the respondents to feel at ease within their own environment and allowed them to speak freely (Polsky, 1969; Wright, Decker, Redfern, and Smith, 1992). For the purpose of this study, each participant was provided an assigned pseudonym for the research project and interview. The research and interviews were conducted from August 2015 to December 2017. The research project was approved through the Institutional Review Board and the Office of Research Compliance through the University. The interviews typically lasted between 45 minutes to an hour, were audio-recorded, and then transcribed. A high percentage of the interviews occurred 'in the street' where the respondent felt more comfortable, although some interviews were conducted in fast-food restaurants, at their homes, and in cars. After consenting to participate in the interview, respondents were asked to talk about the most recent appointment robbery that they were involved in. This style of structural, descriptive, and contrast questions allowed the respondent to talk about a precise series of events directly related to appointment robbery (Spradley, 1979). During the interview, the researcher prompted respondents with questions about why they participated in appointment robbery, their perceptions of the rewards and risks, as well as their specific situation decisions prior, during, and after their commission of appointment robbery.

In order to identify the active offenders, snowball sampling was used to recruit participants from the streets of the metropolitan area (Chambliss, 1975; DeShay, Vasquez, Vieraitis, 2020; Polsky, 1969; Sudman, 1976; Vasquez \& Vieraitis, 2016; Watters \& Biernacki, 1989; West, 1980). The author, a gang interventionist, collected the data and had the ability to identify a gatekeeper through prior contact (McCall, 1978). The gatekeeper was an active appointment robber who had a strong reputation among the criminal underworld and had connections with networks of criminals (DeShay, Vasquez, Vieraitis, 2020; Taylor, 1985; Vasquez \& Vieraitis, 2016; Wright, Decker, Redfern, Smith, 1992). The researcher had known the gatekeeper for five years at the time of the study. The informant's reputation aided the researcher in being introduced to the informant's criminal associates and appointment robbing crews who were also actively participating in criminal activity (McCall, 1978; Taylor, 1985; Wright, Decker, Redfern, Smith, 1992). Since the informant had a strong reputation in the streets, the informant was able to help clarify the research objectives to potential respondents and to validate the researcher as a non-threatening individual to their legal and social status (Biernacki \& Waldorf, 1981; DeShay, Vasquez, Vieraitis, 2020; Irwin, 1972; Vasquez \& Vieraitis, 2016). When each interview was completed, the researcher asked the respondent to provide any referrals.

Respondents range in age from 16 to 26 years old. There were three Caucasians, three African Americans, and six Latinos, and all were male. The respondents in this study came from various types of family units ranging from single-parent, two-parent, and multiple family households. At the time of the interview, all of the juveniles were enrolled in a public school system and the adults were either employed as part time status or employed full time in a manual labor type of employment. A high proportion of the respondents came from a low socioeconomic background; however, four were considered upper middle class. A high number of respondents lived in an area that is classified as 'high poverty' with 27.1 percent of childhood poverty rate and seventy-one percent of all students were qualified for free or reduced lunch at school in 2017 in this area (Children's Health, 2019). The area from which the respondents reside in is known to be infested with gangs, drugs, as well as being known for high teen pregnancy rates at 10.9 per 1,000 females (Children's Health, 2019). The school district which the respondents attend annually reports 112 gangs within the district (M., Dovick, personal communication, 2013). 
Each transcribed interview was read and deductively manually coded based on how the offender made sense of their crime using Jeffery's 1971 crime prevention through environmental design theory as a guide (Strauss, 1987). The aim of this study was to comprehend the ways in which appointment robbers noticed any CPTED strategies while committing crime. As was discovered during coding, one-hundred percent of the respondents recognized one or more of Jeffery's CPTED strategies. The main argument for CPTED is that individuals will not commit a crime if they perceive the potential costs outweigh the rewards. To answer this, the researcher made a note of the specific reasons the respondents provided for why they decided to commit or decided not to commit appointment robbery based on the crime prevention through environmental design strategies. Respondents were specifically asked what event, if any, would deter them from participating in appointment robbery. Additionally, respondents were asked, what event if any, would deter them from committing an appointment robbery at a specific location. Respondents identified various reasons which are presented in the next section.

\section{Results}

Prior research has discussed reasons why robbers decide to commit criminal activity from weighing the costs and benefits (Cornish \& Clarke, 1986), anticipated rewards (Bennett \& Wright, 1984), alert and motivated opportunitism, (Bennett \& Wright, 1984; Topalli \& Wright, 2004; Wilson, 2019), spontaneous and impulsive (Alarid, Burton, \& Hochstetler, 2009), and to a need to prolong surpluses (Jacobs \& Wright, 1999). However, no research has directly discussed the reasons that would decrease the opportunities of appointment robbery based on crime prevention through environmental design (CPTED) strategies while using the voices of active offenders. As respondents provided several reasons why they rob, they frequently offered specific details on how they plan, decide, and ultimately commit appointment robbery. These details are directly associated with the design of the location in which the crime will occur. A goal for appointment robbery may be to obtain a financial reward; however, the question posed is what municipalities can do to decrease appointment robbery in their jurisdictions based on the offenders' own narrative. The data suggest that while there are motivations to commit appointment robbery (Alarid, Burton, \& Hochstetler, 2009; Bennett \& Wright, 1984; Cornish \& Clarke, 1986; Jacobs \& Wright, 1999; Topalli \& Wright, 2004;), the offender may be deterred from committing a crime, such as an appointment robbery, at a specific location based on a particular design of the location (Anastasia and Eck, 2007; Armitage \& Monchuk, 2011; Armitage, Monchuk, \& Rogerson, 2011; Rostami and Madanipour, 2006; Sakip and Abdullah, 2010). Interviews of active appointment robbers revealed that they select locations based on the lack of crime prevention through environmental design strategies. Respondents also identified specific locations that they preferred to rob someone as compared to locations that they would not. This is why the value of CPTED strategies in the prevention of crime is important to investigate through the narratives of offenders. Respondents were asked to recall the most recent appointment robbery they were involved in to discuss specific aspects of the location and target, to identify why they decided to commit an appointment robbery, or why they did not decide to commit appointment robbery. The study does not use the respondent's true name; each respondent was assigned a pseudonym for this study to protect their identity and to ensure confidentiality.

\section{Territoriality}


The strategy of territoriality is to encourage a sense of ownership in order to discourage opportunities for criminal offenders. Territoriality uses design strategies to specify a space as semiprivate, private, or public. This can be done by the use of landscaping, art, and signs to identify the type of space. Seventy-five percent of the offenders did recognize areas that promote ownership as Taylor stated,

When I start to set up a meeting place, I always ask for the address so I can google it to see what kind of neighborhood it is in. If it is too nice, then I know I might not fit in when I go to the meet.

When probed to expound on the offender's perspective of what is meant by a nice neighborhood, Taylor said,

Shit, like if I know that the area has their own security and gates to get into their neighborhood or like if their yards are all taken care of and they have a bunch of decorations out on the yard, then I know dem fuckers will be all nosey when I roll up in my g-ride.

Other respondents were asked to describe locations they would feel more comfortable to commit robbery which Robert summarized as,

Man, I like to tell them to meet me up like at some random neighborhood that I know. I just give them an address, and I tell em that I'm going to be outside on my way out, so like they think I live there, but I really don't. I just want a place where I can blend in and where I know aint nobody gonna be in my business.

Seventy-five percent of the offenders often decided not to rob an individual when the physical environment was able to create a perceived zone of territorial influence. It was discovered that respondents at one point in time decided not to commit an appointment robbery based on their perceived risks when they thought the area had a sense of ownership. The most common theme when they decided not to commit an appointment robbery was when they felt the physical design made it appear the area was well maintained. When offender Taylor saw that a neighborhood looked well maintained, he felt

nervous in places that that I know looks too nice and shit, cuz I know they be having rent-a-cops rolling around looking for shit that don't fit in, you feels me.

When asked to explain their perception of an area being 'well maintained,' respondents frequently talked about symbolic barriers such as signage that indicated the area's name. Michael stated that if he went to meet someone, and the area looked like it is very well protected, then he would tell the seller than he changed his mind and cancel the meet up or even meet up and tell the seller that he was no longer interested. Michael expounded on this by stating,

If they ask me to meet up in an area that had like those special signs on top of their street signs or if I saw signs that said sum shit like, 'Now entering 
some neighborhood', then I would feel like, uncomfortable and cancel that shit.

Respondent Steve also indicated that he would not rob an individual in an area that had 'special neighborhood signs', when he stated,

\section{Hellz naw, I ain't goin' to hit a lick in a hood that has those signs on top of} the street names cuz those are protected hoods.

The special signs that Michael and Steve referred to were the neighborhood revitalization signs. These signs provided a symbolic barrier for the offender since the area promoted that the area had a high sense of ownership.

\section{Natural surveillance}

Natural surveillance increases the opportunity of observations in an area with the use of proper placement of landscaping, lighting, and windows (Peak, 2013). The goal of natural surveillance is to have continuous observation of any potential offenders. Physical features can be modified and areas could be designed so that an area is constructed in a way to maximize surveillance opportunities (Sohn, 2016). When respondents debated their decision to either rob someone or not to rob someone, one-hundred percent of the respondents discussed about the risk of being seen during the commission of their crime. As a way to reduce their chances of being seen during their crime, offenders often attempted to restrict the target selection to places that have fewer 'eyes on the street.' Respondent Mark stated,

When I set up a place to meet up, I never tell em to meet me at a gas station or shopping strip, shit those places are always busy with people.

When probed to describe an area where they would commit an appointment robbery, James said,

I always pick an area that is not very busy, like away from the stores and streets, or an area that is by a lot of businesses that are already closed." The researcher then asked if he would meet up at a specific time of the day, to which James responded, "Yeah, I try to set up the meet later in the day, by a closed store, but not at night, but like when it starts to get dark.

James further expounded that if he thought someone passing by could see him then he would tell the seller,

naw man, I don't want it no more" or that "it was not what he wanted after all.

What Mark and James were describing was selecting a location to commit an appointment robbery that was protected by tall buildings and out of the surveillance of formal and informal users. 
Natural surveillance could be viewed as a form capable guardianship since this strategy could decrease crime because a potential offender perceived they were being observed, even though they were are not. Respondent Jacob stated that he would not show up to rob someone if he felt like he was being watched. When asked to explain, Jacob stated,

I always show up to the area early so I can look around, and if I see a bunch of lights, cameras, and people, it just makes me nervous cuz I know that I could be caught, so like, then I would tell that person that I'm running late and shit or just not show up." He further said, "It's funny how close that person came to be robbed by me.

Even though Jacob was not sure if the lights would illuminate on him, or if the camera actually worked, or even if the people would notice him, he said,

I ain't risking it, I don't know if they be watching or not, but it ain't worth doing that little 'lick' (robbery) and getting caught up.

\section{Activity Support}

Activity Support refers to encouraging outdoor happenings by the location and planning of public space for safe activities. The strategy of activity support encourages acceptable behavior by using signage and design to promote the use of public space as a 'safe location.' When there are safe activities, it attracts non-criminal individuals who then become part of the system of natural surveillance, resulting in their participation to discourage would-be offenders to commit crime (Cozens, Saville, \& Hiller, 2005). Safe locations are identified by the placement of 'safe place' signs to promote and attract legitimate users to engage in activities such as monetary transactions (e.g., selling or buying items from classified advertisements).

This 'safe place' sign informs the public that the location provides surveillance as well as provides a high level of visibility (Cozens \& Love, 2015). Although these 'safe' signs are not typically located in areas where offenders would choose to rob, one-hundred percent of the respondents did mention that they would not select a location to rob someone if they saw the "safe place' sign present. Charles specifically stated that

hell naw, I would never meet up or rob someone if they selected a location that had one of those fucking 'safe place' signs, cuz you know those places all have cameras and shit.

Even though Charles was not sure if the place had cameras, as long as he saw the safe place sign, he perceived it as a location that had numerous cameras as well as a place that law enforcement frequently visited. Charles expounded,

those safe signs make me nervous, cuz you never know who is watching. Sometimes I see those bitches at gas stations and shit, and I'm like, are they recording now cuz I can't see the camera" Another respondent Max also stated similar concerns about 'safe place' areas by stating, "those places that have those signs are fucking hot with cops and cameras. Erry time I 
see one of those stupid signs, I always see cops cruising by or inside that store getting something.

Another strategy of activity support is that it can include such things as allocating for open public space, promoting public activities in open community areas, and implementing walkways (Sohn, 2016). When areas are designed to increase public activity, it also increases the opportunities for surveillance (Crowe, 2000). Respondents such as Taylor stated that he would not rob someone if he visibly saw people near-by participating in daily activities. When asked to elaborate on what he meant, Taylor said,

Shit, you know if they tell me to meet them at a neighborhood, and I show up and I see people all outside, washing cars, and jogging and shit. You know they gonna see or hear me if I try to rob someone.

Similarly, Derrick expressed the same concerns when he reported that, "I am nott trying to rob someone right out in front of everyone, I am not that stupid." When Derrick was asked to describe a good place to rob someone, he said,

I would hella not pick a place that is crowded and I would not pick a place is has a lot of people coming and going. I would make sure to pick an older neighborhood or an apartment complex where there are less people around.

\section{Access Control}

The strategy of access control is aimed at decreasing criminal opportunities by increasing the perception of risk in potential offenders. Access control refers to the design strategy which aims to decrease opportunities for crime by denying access to potential targets as well as generating an increased awareness of risk for the would-be offender (Cozens, Saville, \& Hiller, 2005; Mair \& Mair, 2003). Eighty-three percent of the offenders indicated that they did recognize access control strategies. At the neighborhood level, the physical elements can include such things as implementing local neighborhood parking restrictions, closing off traffic through specific streets, and other features that could induce psychological barriers for the offender (Cozens, 2002). Access control strategy depends on physical elements to create psychological barriers for potential offenders. When offenders saw even a small barrier, it introduced a psychological barrier by making them aware of the increased risk of committing the appointment robbery. Edward stated that a simple 'one-way' traffic design made him nervous since he knew that he would have a difficult time trying to escape. Edward said,

Man, if they wanna meet at a busy area like with a lot of stores and shit, I'm cool with it since I know they will have lots of ways to get out. But man, when I see those 'one-way' street signs, shit, then I know it will be hard to do it, and den there's traffic and shit.

The physical elements also attempt to keep unauthorized individuals out of communities. This strategy was noticed by Rick who stated that, 
If the bitch picks a spot to meet that is out in the open and has only one way in and out, then I'd tell 'em to pick another place, but I'd say some shit like, 'I'm running late and I know of another place closer'. That way I get to pick a spot that is easier to get away, you feel me.

The location respondents primarily selected was chosen on whether or not the offender perceived they had easy access with multiple entrances and exits. Respondents picked a location that had an easy access to escape routes, as Edward stated,

When I set up a robbery, I always pick a place that has lots of exits and is close by freeway, cuz if you have to bounce real quick like, then I can.

Access control also encompasses the strategic placement of lighting and cameras to increase the risk of being seen by pedestrians. One of the main goals for offenders is to not be seen by others as they commit crime. Respondents discussed their heightened awareness of being seen when lights and cameras were present while committing an appointment robbery. Respondent Adam talked about this while he discussed the risks of committing appointment robbery,

Shit, as soon as I pull up I always look for cameras and lights, cuz I ain't trying to get caught up on camera and shit. But for realz, I'll show up a little bit early so like if I see a camera, I will park away from it so they don't get my plate or my face.

Respondent Steve also mentioned lights and cameras when he said, "I always try to have the meet up at the edge of a parking lot or away from places that have stores since I know they will have lights, cameras, and lots of people." When Steve was asked: 'Do lights and cameras deter you from committing a robbery?' Steve responded by saying,

Hell yeahs. If I can't get the guy to meet up at another location, and they want to meet at a place that has those stupid 'yellow safe' signs, then I know I ain't gonna do it, cuz then if I rob da bitch, then I know that they be recording me. Or like if they want to meet up right by the front of a store, den I know there will be a shit load of lights and cameras. That's why I always be da one to set up the meet first, and not let them pick a place.

\section{Discussion}

In this study, we examined whether the perceptions of active appointment robbers were influenced by the strategies of crime prevention through environmental design that are implemented by municipalities. Interviews with respondents revealed that they did dedicate time to think about getting caught, potential consequences, and the risks of offending as it related to target and location selection. Respondents did use personal strategies in an effort to reduce the likelihood of getting apprehended. More specifically, respondents discussed the significance of having a plan, which consisted of various crime specific measures to decrease the chance of detection, before committing an appointment robbery. In having a particular plan prior to robbing someone, respondents were able to reduce their perceived threat of detection and apprehension by informal and formal agents of social control. We found that when CPTED strategies were 
implemented, they had an impact on the decision-making behavior of the offender. When CPTED strategies are properly applied, they can deter potential criminal behavior in those specific areas since it increases the offender's perception of being observed, thereby increasing their perception of risk in committing an appointment robbery, resulting in the decision not to commit the appointment robbery.

The study did find support for the four CPTED strategies as introduced by Jeffery (1971); (1) territoriality, (2) natural surveillance, (3) activity support, and (4) access control. The roles of the strategies are significant factors for the respondents in deciding on the target location to commit an appointment robbery. The research did find that physical and symbolic features did have a direct influence in deciding the target location. The strategy of territoriality was supported when the offenders recognized the sense of ownership of an area by visibly seeing the gates, maintained landscape, and specialized signs to identify the type of space. When ownership is felt by the offender, it decreased the likelihood that the offender would commit the crime. Additionally, with regards to neighborhood revitalization signs, while they are meant to indicate the neighborhood received grant money to clean up the community, it was a surprising finding that offenders often correlated these signs with a sense of ownership, and then decided not to commit the crime. Natural surveillance was supported when offenders stated that they would attempt to set up a robbery in locations that was away from the view of others with low surveillance. If the respondents could not pick a location that was away from pedestrians, then they would not commit the appointment robbery.

The strategy of activity support was supported through the use of 'safe zone' signs. Onehundred percent of the respondents reported that they would stay away from committing crime near a location that had a 'safe zone' sign because they knew that the location had working cameras, lights, and was associated as a location that law enforcement were present or visited frequently. Also, when respondents witnessed individuals outside participating in daily neighborhood life they would not commit the appointment out of fear of being seen or not fitting in. This finding is in line with Jane Jacobs (1961) who said that the more individuals on the streets, the safer the individuals become since their 'eyes on the street' create informal surveillance for the neighborhood. Lastly, the strategy of access control is also supported by this research. When the respondents viewed the physical features as potential barriers, they stated it also created a psychological barrier often increasing their risk perception which often prompted them to decide not to commit the crime. Once offenders noticed that a location had few exits and entrances, it made them nervous since it limited their escape routes. Overall, one-hundred percent of the respondents indicated that when CPTED strategies were present it helped them to decide not to commit the crime since they perceived the risk was too great for the potential reward.

\section{Conclusion}

It is understood that our research does have limitations. First, the sample population was small and therefor our findings cannot be generalized. In theory, all research should have (when possible) used probabilistic sampling methodology, however it was nearly impossible to do this in the field (Bernard, 1995; Trotter \& Schensul, 1998). This is particularly true as in this case for stigmatized, hard-to-reach or hidden populations (Guest, Bunce, \& Johnson, 2006). While our sample population is small it was understood that data saturation had occurred by the time twelve interviews had been analyzed (Guest, Bunce, \& Johnson, 2006). The aim of the study is not to generalize appointment robbers who select their targets and locations arising from the use of online or app advertisements at large. The study focus was to provide an opportunity to tell the story of a 
select few appointment robbers and their decision-making process as it related to CPTED strategies.

Social desirability response is the second limitation that could have influenced the data. Since respondents were acquired from a well-respected offender, some may have answered in a way they believed to be more socially acceptable for their peers than would be their 'true' response. The respondents could have done this as a way to display a favorable criminal self-image and to evade receiving negative evaluations from their peers. To address this limitation, the researcher attempted to develop a rapport with each respondent prior to the semi-structured interview. This was done to make the respondent feel at ease with openly talking with a researcher as compared to being asked to participate from a well-respected offender.

While we acknowledge this study has limitations, our research contributes to what is known about CPTED theory and its effects on target and location selection by using the voices of offenders which have previously been omitted in the literature. The findings are relevant to future ideographic research of how adoption of CPTED strategies can have an effect on the decision-making process of would-be offenders. This research confirmed the importance of CPTED strategies in deterring possible crime. The research also found that in order to reduce crime arising from appointment robberies, municipalities ought not to only depend on formal tactics (criminal justice system) to curtail appointment robbery, but should implement proactive strategies of CPTED in crime reduction policies. Therefore, this study provides relevant implications for scholars and practitioners to take into account for the future. The exploration of the data presented in the research offered an account of the struggles faced by municipalities as they deal with a new $21^{\text {st }}$ century problem in their jurisdiction.

Future research ought to investigate any potential reduction in appointment robberies with increased implementation of CPTED strategies in a specific area. Moreover, not many municipalities utilize CPTED strategies, and more specifically, numerous jurisdictions do not have an official policy mandating area for 'safe transaction zones. Municipalities ought to consider including guidelines to officially develop, maintain, and support CPTED strategies in an effort to reduce appointment robberies and other crimes. Since not all municipalities use CPTED strategies, it would be valuable research to examine any potential differences in appointment robberies. Also, if other municipalities are not enacting CPTED strategies, it would be important to examine which factors contributed to decision of not using CPTED as a component in their crime reduction policy. Lastly, research should study any changes amongst other types of crimes where CPTED strategies were recently implemented.

Our research provides an understanding into the decision-making behavior of appointment robbers, specifically the study offers insight into how CPTED strategies, when implemented, did influence the decision-making behavior of the offender and thereby suggest future policy implications. First, policymakers should encourage and support the use of CPTED strategies which reduce the opportunity for offenders to commit an appointment robbery. Respondents of this study admitted that they would not commit an appointment robbery if the CPTED strategies were implemented at a target location. While CPTED strategies are unlikely to completely eliminate appointment robbery, they have the potential to decrease the amount of appointment robberies. Second, policymakers should designate specific areas within the municipality as a 'safe transaction zone' to conduct the face-to-face financial transactions. These 'safe transaction zones' are grounded in CPTED theory since the safe space is typically located at a public municipality building (e.g. law enforcement), well-lit, and is usually monitored by a surveillance system. Respondents of this study indicated that location to commit crime was important. Therefore, eliminating or at least decreasing the opportunities for offenders' ability to gain access to a specific 
area could help to decrease and even prevent appointment robbery. Third, law enforcement, policymakers, and community leaders should make an effort to effectively communicate to their local communities of the 'safe transaction zones' and the increased risk for an appointment robbery if they are not utilized to complete face-to-face financial transactions. Lastly, the leaders of the community are needed to promote members of the community to get involved in prevention activities.

\section{References}

Adler, P. A, \& Adler, P. (2006). The deviance society. Deviant Behavior, 27, 129-148.

Alarid, L. F., Burton, V. S., \& Hochstetler, A. L. (2009). Group and solo robberies: Do accomplices shape criminal form? Journal of Criminal Justice, 37, 1-9.

Anastasia, L.S. \& Eck, J. (2007). Crime prevention and active living. American Journal of Health Promotion, 21(4), 380-389.

Anderson, J., MacDonald, J. M., Bluthenthal, R., \& Ashwood, S. (2013). Reducing crime by shaping the built environment with zoning: An empirical study of Los Angeles. University of Pennsylvania Law Review, 161, 699-756.

Armitage, R. (2006). Predicting and preventing: Developing a risk assessment mechanism for residential housing. Crime Prevention and Community Safety: An International Journal, $8(3), 137-149$.

Armitage, R. (2013). Crime prevention through housing design: Policy and practice. Basingstoke. UK: Palgrave Macmillan.

Armitage, R. (2018). Burglar's take on crime prevention through environmental design (CPTED): Reconsidering the relevance from an offender perspective. Security Journal, 31(1). 285304.

Armitage, R. \& Monchuk, L. (2011). Sustaining the crime reduction impact of designing out crime: Re-evaluating the secured by design scheme 10 years on. Security Journal 24(4), 320-343.

Armitage, R., Monchuk, L., \& Rogerson, M. (2010). It looks good, but what is it like to live there? Exploring the impact of innovative housing design on crime. European Journal on Criminal Policy and Research, 17(1), 29-54.

Beavon, D., Brantingham, P. I. \& Brantingham, P. J. (1994). The influence of street networks on the patterning of property offenses, in Clarke, $R$. V. (Ed.). Monsey, NY: Criminal Justice Press.

Bennett, T. \& Wright, R. (1984). Burglars on burglary. Prevention and the offender. Vermont: Gower Publishing Company.

Bercovici, J. (2011, February, 24). Craigslist called "cesspool of crime” by rival. Low blow? Forbes. $\quad$ Retrieved September 23, 2019, from http://www.forbes.com/sites/jeffbercovici/2011/2/24/craigslist-called-cesspool-focrimeby-rival-low-blos/

Berk, R. A., \& Adams, J. M. (1970). Establishing rapport with deviant groups. Social Problems, $18,102-117$.

Bernard, H. R., (1995). Research methods in anthropology. Walnut Creek, CA: AltaMira.

Bernasco, W. \& Nieuwbeerta, P. (2005). How do residential burglars select target areas? A new approach to the analysis of criminal location choice. British Journal of Criminology, 45(3), 296-315.

Biernacki, P. \& Waldof, D. (1981). Snowball sampling: Problems and techniques of chain referral sampling. Sociological Methods \& Research, 10, 141-163. 
Brown, B. B. \& Altman, I. (1983). Territoriality, defensible space and residential burglary: An environmental analysis. Journal of Environmental Psychology, 3(3), 203-220.

Brown, B. B. \& Bentley, D. (1993). Residential burglars judge risk: The role of territoriality. Journal of Environmental Psychology. 13, 51-61.

Carter, S. P., Carter, S. L. \& Dannenberg, A. L. (2003). Zoning out crime and improving community health in sarasota, florida: "Crime prevention through environmental design". American Journal of Public Health, 93(9), 1442-1445.

Chambliss, W. (1975). On the paucity of research on organized crime: A reply to galliher and cain. American Sociologist, 10, 36-39.

Children's Health. (2019). Beyond ABC: Assessing the well-being of children in north texas 20192020. Retrieved from https://www.childrens.com/beyondabc

Choo, K, Kwang, R., \& Smith, R. G. (2008). Criminal exploitation of online systems by organized crime groups. Asian Journal of Criminology, 3, 37-59.

Cilluffo, F. J., Cardash, S., L., \& Whitehead, A. J. (2007). Radicalization behind bars and beyond borders. Brown Journal of World Affairs, 13, 113-122.

Consumer Federation of America. (2018). 2017 Consumer complaint survey report. July, 30, 2018. Retrieved from https://consumerfed.org/wp-content/uploads/2018/07/2017-consumercomplaint-survey-report.pdf

Cornish, D. B. \& Clarke, R. V. (1986). The reasoning criminal: Rational choice perspectives on offending. New York: Springer-Verlag.

Cornish, D. B. \& Clarke, R. V. (2003). Opportunities precipitators and criminal decisions: A reply to wortley's critique if situational crime prevention, In: M. J. Smith and D. B. Cornish (eds.) Theory for practice in situational crime prevention, crime prevention studies, vol. 16. Monsey, NY: Criminal Justice Press.

Cozens, P. \& Love, T. (2015). A review and current status of crime prevention through environmental design (CPTED). Journal of Planning Literature, 30(4), 393-412.

Cozens, P. M. (2002). Sustainable urban development and crime prevention through environmental design for the british city. Towards an effective urban environmentalism for the $21^{\text {st }}$ century. Cities, 19(2), 129-137.

Cozens, P. M., Saville, G., \& Hillier, D. (2005). Crime prevention through environmental design (CPTED): A review and modern bibliography. Property Management, 23(5), 328-356.

Cromwell, P. F., Olson, J. N. \& Avary, D. W. (1991). Breaking and entering: An ethnographic analysis of burglary. Newbury Park, CA: Sage.

Cromwell, P., \& Birzer, M. L. (2014). In their own words: Criminals on crime: An Anthology. $6^{\text {th }}$ ed. New York, NY: Oxford University Press.

Crowe, T. D. (2000). Crime prevention through environmental design: Applications of architectural design and space management concepts. $2^{\text {nd }}$ ed. Oxford, UK: ButterworthHeinemann.

Cullen, F. T., Agnew, R., \& Wilcox, P. (2013). Criminological theory: Past to present: Essential readings. $5^{\text {th }}$ Ed. New York, NY: Oxford University Press.

Davis, J. T. (2012). Examining perceptions of local law enforcement in the fight against crimes with a cyber component. Policing and International Journal of Police Strategies \& Management, 35(2), 272-284.

Decker, S. H. \& van Winkle, B. (1996). Life in the gang: Family, friends, and violence. Cambridge, UK: Cambridge University Press.

DeShay, R. A., Vasquez, A., \& Vieraitis, L. M. (2020). "You gotta have a plan so you won't get caught": Managing the risks of street tagging. Deviant Behavior, 1-18. 
Durkin K., F. \& Brinkman, R. (2009). 419 Fraud: A crime without borders in a postmodern world. International Review of Modern Sociology, 35, 271-283.

Durkin, K. \& Patterson, D. (2011). Cyber bullying, cyber harassing, and cyber stalking. p. 450-455 in The handbook of deviant behavior, Edited by Clifton D. Bryant. New York, NY: Routledge.

Durkin, K. F. (2013). The dawn of a new era: Renewed prospects for the sociology of deviance in the internet age. In Alex C. Thio, Thomas C. Calhoun, \& Addrain Conyers (Eds.), Deviance Today, 265-271. Boston, MA: Pearson.

Eck, J. (1997). Preventing crime at places: Why places are important, in Sherman, L. W., Gottfredson, D.C., Eck J., Reuter, P. and Bushway, S.D. (Eds), Preventing Crime: What works, what doesn't, What's promising. Washington, D.C.: National Institute of Justice Research in Brief, U.S. Department of Justice.

Glassner, B., \& Carpenter, C. (1985). The feasibility of an ethnographic study of property offenders: A report prepared for the National Institute of Justice. Washington, DC: NIJ Mimeo.

Goodnough, A., \& O’Conner, A. (2010). Boston craigslist case: Med student's preppy profile. Seattle Times. Retrieved September 22, 2019 from https://www.seattletimes.com/nationworld/boston-craigslist-case-med-students-preppy-profile/

Greenberg, S. \& Rohe, W. (2007). Neighborhood design and crime: A test of two perspectives. Journal of the American Planning Association, 50(1), 48-61.

Groff, E. R. \& LaVigne, N. G. (2001). Mapping an opportunity surface of residential burglary. Journal of Research in Crime and Delinquency, 38(3), 257-278.

Guest, G., Bunce, A., \& Johnson, L. (2006). How many interviews are enough? An experiment with data saturation and variability. Field Methods, 18(1), 59-82.

Hillier, B. (2004). Can streets be made safe? Urban DESIGN International, 9, 31-45.

Hillier, B. \& Shu, S. (2000). Crime and urban layout: The need for evidence, in Baltimore, S., Pease, K., \& McLaren, V. (Eds.), Secure foundations: Key issues in crime prevention, crime reduction and community safety, Institute of Public Policy Research, London, 224-2248.

Hinduja, S. (2007). Computer crime investigations in the United States: Leveraging knowledge from the past to the address the future. International Journal of Cyber Criminology, 1(1), $1-27$.

Hochstetler, A. (2001). Opportunities and decisions: Interactional dynamics in robbery and burglary groups. Criminology, 39(3), 737-764.

Holtz, J. (2010). Craigslist murder, robbery suspects charged. HeraldNet. Retrieved September 22, 2019 from https://www.heraldnet.com/news/craigslist-murder-robbery-suspects-charged/

Irwin, J. (1990). Participant observation of criminals. P. 117-137 in Research on deviance, edited by jack Douglas, New York: Random House.

Jacobs, B. A., \& Wright, R. (1999). Stick-up, street culture, and offender motivation. Criminology, 37, 149-173.

Jacobs, J. (1961). The death and life of great american cities. New York: NY. Random House.

Jeffery, C. R. (1971). Crime prevention through environmental Design. Beverly Hills, CA: Sage.

Kajalo, S., \& Lindblom, A. (2015). Creating a safe and pleasant shopping environment: A retailer's view. Property Management, 33(3), 275-286.

Lee, H. (2012). Craigslist users fall prey to robberies. San Francisco Gate. Retrieved September 24, 2019, from http://sfgate.com/crime/article/Craigslist-users-fall-prey-to-robberies3826141.php 
Mair, J. S. \& Mair, M. (2003). Violence prevention and control through environmental modifications. Annual Review of Public Health, 24, 209-225.

Maxfield, M. G., \& Babbie, E. (1995). Research methods for criminal justice and criminology. Belmont, CA: Wadsworth.

McCall, G. (1978). Observing the law. New York: Free Press.

McKenzie, M. (2011). Craigslist crime "study" - Sour grapes \& cheap wint. Allbusiness. Retrieved on September 23, 2019 from http://www.allbusiness.com/crime-law/crime-statistics-crimerate/15479949-1html

Mills, C. W. (1940). Situated actions and vocabularies of motive. American Sociological Review, 56(6), 904-913.

Nee, C., \& Meenagham, M. (2006). Expert decision making in burglars. British Journal of Criminology, 46, 935-949.

New Jersey Commission of Investigation and Attorney General of New Jersey. (2000). Computer crime: A joint report. Trenton, NJ.

Newman, O. (1972). Defensible space: Crime prevention through urban design. New York: NY. The Macmillan Company.

Newman, O. (1973). Defensible space: People and design in the violent city. London, UK: Architectural Press.

Newman, O. (1980). Community of interest. Anchor Press / Doubleday, New York, NY.

Oravec, Jo Ann. (2014). Craigslist in crisis: Issues of censorship and moral panic in the context of online communities. International Journal of the Academic Business World, 8(2), 1-11.

Ortiz, M. J. (2018). Gangs and environment: A comparative analysis of prison and street gangs. American Journal of Qualitative Research, 2(1), 97-117.

Patton, M. (1987). How to use qualitative methods in evaluation. Thousand Oaks, CA: Sage Publications.

Patton, M. Q. (2002). Qualitative research \& evaluation methods. $3^{\text {rd }}$ Ed. Thousand Oaks, CA: Sage Publications.

Peak, K. (2013). Encyclopedia of community policing and problem solving. Reno: Sage.

Petterson, G. (1997). Crime and mixed-use development, in Coupland, A. (Ed.). Reclaiming the city: Mixed use development (pp. 179-202). London: Routledge.

Polsky, N. (1969). Hustler, beats, and others. Garden City, NJ: Anchor.

Poyner, B. (1983). Design against crime: Beyond defensible space. London: Butterworth.

Poyner, B., \& Webb, B. (1991). Crime free housing. Oxford: Butterworth-Architecture, London.

Rostani, L. T. \& Madanipour, A. (2006). Crime and the city: Domestic burglary and the built environment in Tehran. Habitual International, 10 (4), 932-944.

Sakip, S. R. Md \& Abdullah, A. (2010). Measuring crime prevention through environmental design in a gated residential area: A pilot survey. Social and Behavioral Sciences, 42, 340-349.

Sohn, D. W. (2016). Residential crimes and neighborhood-built environment: Assessing the effectiveness of crime prevention through environmental design (CPTED). Cities, 52, 8693.

Spradley, J. P. (1979). The ethnographic interview. Belmont, CA: Wadsworth, Cengage Learning.

Strauss, A. L. (1987). Qualitative analysis for social scientists. Cambridge, UK: Cambridge University Press.

Sudman, S. (1976). Applied sampling. New York, NY: Academic Press.

Taylor, L. (1985). In the underworld. London: Unwin.

Taylor, R. \& Hale, M. (1996). Testing alternative models of fear of crime. Journal of Criminal Law and Ciminology, 77(1), 151-189. 
Toppalli, V., \& Wright, R. (2004). Dubs, dees, beats, and rims: Carjacking and urban violence. In D. Dabney (Ed.), Crime Types: A text reader. Belmont, CA: Wadsworth, 149-169.

Trotter, R. H., \& Schensul. (1998). Methods in applied anthropology. In Handbook of methods in cultural anthropology, ed. H. R. Bernard, 691-736. Walnut Creek, CA: AltaMira.

Tseloni, A., Thompson, R., Grove, L. \& et al. (2014). The effectiveness of burglary security sevices. Security Journal, 30 (2), 646-664.

U.S. Department of Justice. (2010). Crime in the united states 2010: Offense definitions. Federal bureau of investigation. Retrieved from https://ucr.fbi.gov/crime-in-the-u.s/2010/crime-inthe-u.s.-2010/offense-definitions

Van der Voordt, T. J. M., \& Van Wegen, H. B. R. (1990). Testing building plans for public safety: Usefulness of the delft checklist. Netherlands Journal of Housing and Environmental Research, 5(2), 129-154.

Vasquez, A., Vieraitis, L. M. (2016). "It's just paint": Street taggers' use of neutralization techniques. Deviant Behavior, 37(10), 1179-1195.

Watters, J. Biernacki, P. (1989). Targeted sampling: Options for the study of hidden populations. Social Problems, 36, 416-430.

West, W. G. (1980). Access to adolescent deviants and deviance. P. 31-44 in Fieldwork experience, qualitative approaches to social research, edited by William Shaffir, Robert Stebbins, and Allan Turowitz. New York, NY: St. Martin's.

White, G. F. (1990). Neighborhood permeability and burglary rates. Justice Quarterly, 7(1), 5767.

Williams, K. (2008). Using tittle's control balance theory to understand computer crime and deviance. International Review of law Computers \& Technology, 22(1-2), 145-155.

Wilson, K., P. (2019). Am I Invisible?! Millennial Invisibility in America. Journal of Ethnic and Cultural Studies, 6(2), 13-26. doi: http://dx.doi.org/10.29333/ejecs/221

Winchester, S. \& Jackson, H. (1982). Residential burglary: The limits of prevention. London: Home Office.

Wortley, R. \& McFarlane, M. (2011). The role of territoriality in crime prevention: A field experiment. Security Journal, 24(2), 149-156.

Wright, R. T. \& Decker, S. (1994). Burglars on the job: Streetlife and residential break-ins. Boston, MA: Northeastern University Press.

Wright, R. T., Decker, S. H., Redfern, A. K., \& Smith, D. L. (1992). A snowball's chance in hell: doing fieldwork with active residential burglars. Journal of Research in Crime and Delinquency, 29(2), 148-161.

\section{Biographical Note}

Arthur Vasquez is a $\mathrm{PhD}$ student in Public Administration and Public Policy at the University of Texas at Arlington. His primary interests include juvenile delinquency, gangs, graffiti, theory, qualitative methods, policy, and active offenders.

Alejandro Rodriguez is an Associate Professor in the College of Architecture, Planning and Public Affairs at the University of Texas-Arlington. Professor Rodriguez has a Ph.D. in Public Administration from Florida International University, and a Master's in Public Administration from Marist College, New York. His research interest focuses on public administration theory, culture, government reform, and budgeting. His recent publications include "Conceptualizing Leadership Psychosis: The Department of Veteran Affairs Scandal," "Defining Governance in Latin 
America," and "Cultural Differences: A Cross-cultural Study of Urban Planners from Japan, Mexico, the U.S., Serbia-Montenegro, Russia, and South Korea."

Dr. Jiwon Suh is an assistant professor in the Department of Public Affairs and Planning at the University of Texas at Arlington. Her research interests include organizational behaviors, human resource management, strategic management, performance \& accountability, cross-national \& cross-sectoral comparisons, and nonprofit marketing \& communication. She has published articles in Review of Public Personnel Administration, Public Personnel Management, and Nonprofit Management \& Leadership.

Dr. Maria Martinez-Cosio is an urban sociologist with a Ph.D. from UC San Diego. She researches the relationship between private foundations engaged in community development, and the underserved communities targeted for change, particularly those populated by English-languagelearners.

Manuscript received March 10, 2020

Final revision received April 14, 2020

Accepted April 24, 2020 